\title{
Effects of Spray-Dried Animal Plasma in Calf Milk Replacer on Health and Growth of Dairy Calves ${ }^{1}$
}

\author{
J. D. Quigley, III*† and T. M. Wolfe* \\ *APC, Inc., 1 VisionAire Place, Ames, IA 50010 \\ †Department of Animal Science, lowa State University, Ames 50011
}

\begin{abstract}
Male Holstein calves $(\mathrm{n}=120)$ purchased from local dairy farms were fed one of three calf milk replacers for $42 \mathrm{~d}$. Experimental milk replacers were formulated to contain whey protein concentrate (WPC) as the primary protein source or WPC plus 5\% spray-dried bovine plasma (SDBP) or spray-dried porcine plasma (SDPP). The SDPP was heated to remove heat-insoluble materials and provide products with similar IgG content. Calves were also fed commercial calf starter and water for ad libitum consumption. Intake, change in body weight (BW), feed efficiency, morbidity and mortality were determined. Mortality was 10, 3, and 2 in calves fed WPC, SDBP, and SDPP treatments, respectively. Morbidity, measured as the number of days that calves had diarrhea was reduced by $30 \%$ when SDBP or SDPP were fed. Calves had diarrhea for $6.9,3.9$, and $4.7 \mathrm{~d}$ during the 42-d study when fed commercial calf milk replacer containing WPC, SDBP, and SDPP, respectively. Fecal scores tended to be reduced and feed efficiency tended to be improved when SDBP or SDPP were fed. Mean intakes of total dry matter during the 42-d study were greater when calves were fed SDBP or SDPP and were 661,710 , and $684 \mathrm{~g} / \mathrm{d}$ for calves fed WPC, SDBP, and SDPP, respectively. Mean BW gains from d 0 to 42 were 231,261 , and $218 \mathrm{~g} / \mathrm{d}$, respectively. Calves fed SDPP tended to have lower BW gain during the first $28 \mathrm{~d}$ of the study. However, difference in daily BW gain from d 1 to 28 was only $39 \mathrm{~g} / \mathrm{d}$. Inclusion of SDBP or SDPP in milk replacer reduced morbidity and mortality of milk-fed dairy calves.
\end{abstract}

(Key words: calf, milk replacer, plasma)

Abbreviation key: CMR = commercial calf milk replacer, $\mathbf{C S}=$ commercial textured calf starter, $\mathbf{M E}=$ metabolizable energy, SDBP = spray-dried bovine plasma, SDPP = spray-dried porcine plasma, $\mathbf{W P C}=$ whey protein concentrate.

\footnotetext{
Received February 20, 2002.

Accepted August 23, 2002.

Corresponding author: J. D. Quigley; e-mail: jim.quigley@ amerprotcorp.com.

${ }^{1}$ This research was supported by APC, Inc., Ames, IA.
}

\section{INTRODUCTION}

Commercial calf milk replacer (CMR) formulations are widely used in the industry to supplement or replace saleable milk in the diet of preweaned calves. Typically, CMR are based on dairy ingredients and, in the United States, are formulated using whey protein concentrate (WPC) and whey as the primary protein and carbohydrate sources, respectively (Heinrichs et al., 1995). Other ingredients may include fats (typically tallow, lard, and grease), vitamins, minerals, and additives.

Protein is the most expensive component of CMR, and increasingly, human applications for WPC are being developed. Therefore, alternate proteins in CMR formulations are needed. Many alternative proteins have been evaluated in CMR, including soy proteins, wheat isolate, potato proteins, red blood cells and hydrolyzed blood cells, and bovine plasma (Morrill et al., 1995; Quigley and Bernard, 1996; Quigley et al., 2002), among others.

Blood proteins have traditionally been collected and heated to high temperatures in the manufacture of blood meal, which destroys the functional components of the proteins. Conversely, spray-dried plasma proteins are processed to preserve the functional characteristics of the proteins, including biologically active peptides, such as albumin and IgG. In this process, blood is collected into stainless steel tanks, troughs, or other devices containing an anticoagulant in abattoirs under government inspection. Blood is collected only from animals determined to be fit for slaughter following veterinary inspection. The blood is then transferred to stainless steel tanks, followed by centrifugation and chilling to 4 to $5^{\circ} \mathrm{C}$. Chilled plasma is then transported by dedicated equipment to facilities where it is spray-dried to produce a light brown, freely flowing powder that may be used in feed applications.

Although plasma samples derived from bovine and porcine blood have been compared (Morrill et al., 1995), differences in composition (IgG content) and in methods of processing indicate that further evaluation of bovine and porcine plasma as an alternative protein in CMR is required. Our objective was to determine effects on animal growth and health when calves were fed CMR containing bovine or porcine plasma. 
Table 1. Ingredient composition of experimental diets.

\begin{tabular}{lrrr}
\hline & \multicolumn{3}{c}{ Milk replacer $^{1}$} \\
\cline { 2 - 4 } Ingredient, \% as fed & WPC & SDBP & SDPP \\
\hline Dry fat blend (20\% CP, 40\% fat) & 50.00 & 50.00 & 50.00 \\
Dried whey, 12\% CP & 38.75 & 39.00 & 39.00 \\
Whey protein concentrate, 75\% CP & 6.65 & 1.90 & 1.90 \\
SDBP & 0.00 & 5.00 & 0.00 \\
SDPP & 0.00 & 0.00 & 5.00 \\
Vitamin/mineral premix & 2.50 & 2.50 & 2.50 \\
Dicalcium phosphate, 18.5\% & 2.00 & 1.65 & 1.65 \\
DL-methionine & 0.00 & 0.05 & 0.05 \\
\hline
\end{tabular}

${ }^{1}$ Milk replacer: $\mathrm{WPC}=$ calf milk replacer $(\mathrm{CMR})$ containing whey protein concentrate; $\mathrm{SDBP}=\mathrm{CMR}$ containing $5 \%$ spray-dried bovine plasma; SDPP = CMR containing $5 \%$ spray-dried porcine plasma.

\section{MATERIALS AND METHODS}

Commercially available spray-dried bovine plasma (SDBP; NutraPro B, APC, Inc., Ames, IA) and spraydried porcine plasma (SDPP; APC, Inc.) were used in the study. The SDPP was further processed by heating to $53^{\circ} \mathrm{C}$ for $45 \mathrm{~min}$ in a stainless steel tank. Insoluble material was removed by centrifugation to increase IgG content to levels similar to SDBP. Dried plasmas were stored in 22.7-kg bags until formulated into CMR.

Experimental CMR were formulated to contain 0 or $5 \%$ of the formula (0 or $20 \%$ of CP) as SDBP or SDPP (Table 1). All CMR were formulated to contain $20 \% \mathrm{CP}$, $20 \%$ fat, $0.8 \% \mathrm{Ca}, 0.7 \% \mathrm{P}$ (air-dry basis), and to meet or exceed NRC requirements (2001) for vitamins and minerals and predicted AA requirements (Williams, 1994). The CMR were manufactured at a commercial blending facility (Animix, Juneau, WI), packaged in color-coded 22.7-kg bags and transported to the experimental site. No antibiotics or coccidiostats were added to the CMR.

Holstein bull calves $(n=120)$ were purchased from area dairy farms at approximately $5 \mathrm{~d}$ of age and transported to the APC Animal Research Unit in Ames, Iowa. Calves were received in two groups on October 19 and 26, 2000, and began the study the next day. Calves were assigned to the study if they were visibly free of disease or congenital defect and were ambulatory. Jugular blood was collected into evacuated tubes containing EDTA from each calf on arrival, and a subsample was collected for measurement of hematocrit by microhematocrit centrifuge. Tubes were then centrifuged, plasma was separated, and a subsample was used for determination of total plasma protein by refractometer. The remaining plasma was frozen $\left(-20^{\circ} \mathrm{C}\right)$ until analyzed for IgG by turbidimetric immunoassay (Etzel et al., 1997). Calves were moved to individual fiberglass hutches, fed one dose $(454 \mathrm{~g})$ of a colostrum supplement product (Lifeline Calf Nutritional Colos- trum Supplement; APC, Inc.) and then were assigned randomly to treatment.

Calves were fed CMR twice daily at approximately 0700 and $1600 \mathrm{~h}$. Amounts of CMR offered to calves varied by week and were $454,545,654,726,545$, and $272.5 \mathrm{~g} / \mathrm{d}$ for the 6 -wk study. The DM concentration of reconstituted CMR was $12.0 \%$ for all weeks except wk $3(12.5 \% \mathrm{DM})$ and $4(12.8 \% \mathrm{DM})$. Reconstituted CMR was fed to calves in individual nipple bottles. Amount of CMR offered and refused was measured at each feeding. Commercial textured calf starter (CS; Cargill Herd Builder, Cargill, Inc., Minnetonka, MN) was offered once daily ad libitum beginning on $\mathrm{d} 29$, and feed refusals were measured daily. Water $(6 \mathrm{~L} / \mathrm{d})$ was offered in graduated buckets once or twice daily, and the amount offered and remaining at the end of $24 \mathrm{~h}$ was recorded. No hay was fed. Hutches were bedded with wood shavings throughout the study. Samples of CMR and CS were collected weekly and stored $\left(-20^{\circ} \mathrm{C}\right)$ before analysis for $\mathrm{CP}$, ether extract (Mojonnier assay), $\mathrm{ADF}$ (CS only), ash, and minerals (ICP emission spectroscopy), according to AOAC methods (AOAC, 1990) by a commercial laboratory (Silliker Laboratories of Iowa, Cedar Rapids, IA). The IgG concentrations of bovine and porcine plasma were determined on a $10 \%$ solution of plasma and water using the method of Etzel et al. (1997).

Calves were weighed once weekly at a constant time of the day. Fecal consistency was subjectively scored once daily using a scale of $1=$ normal fecal consistency to $4=$ severe scours according to the method of Larson et al. (1977), except that intermediate units (e.g., 2.5) were also used. When fecal material was unavailable for scoring, calves were assigned a missing value. A scour day was defined when calves had a fecal score $>2$. Rectal temperatures were determined on calves with fecal score $>1$ or when calves appeared depressed, refused CMR, or exhibited behavior consistent with the onset of disease. Treatment with antibiotics was initiated when an animal had a rectal temperature $>39.4^{\circ} \mathrm{C}$ and continued for $3 \mathrm{~d}$. Electrolyte therapy was initiated when calves had fecal score $>2$ and continued until signs of dehydration abated. Daily mean high and low ambient temperatures were obtained from ISU Campbell Network, Iowa State University, Ames.

Daily intake of CS, CMR, water, fecal scores, treatment with antibiotics or electrolytes, and weekly BW and feed efficiency were pooled by week and analyzed as repeated measures ANOVA using the Mixed Procedure of SAS (SAS, 1990). Calf-within-treatment was included in the model as a random effect. The covariance structure was modeled according to Littell et al. (1998), and unstructured covariance was selected. Body weight gain from d 0 to 28,29 to 42 , and 0 to 42 , and 
Table 2. Chemical composition of experimental plasmas used in CMR.

\begin{tabular}{lrr}
\hline Nutrient $^{1}, \%$ & $\mathrm{SDBP}^{2}$ & $\mathrm{SDPP}^{3}$ \\
\hline $\mathrm{DM}$ & 94.02 & 93.61 \\
$\mathrm{CP}$ & 81.47 & 86.01 \\
Fat & 4.48 & 4.18 \\
Ash & 7.56 & 4.53 \\
Calcium & 0.11 & 0.63 \\
Phosphorus & 1.30 & 0.14 \\
Potassium & 0.16 & 0.14 \\
Magnesium & 0.03 & 0.02 \\
\hline
\end{tabular}

${ }^{1}$ Analyses are on a $100 \%$ DM basis, except DM.

${ }^{2}$ Spray-dried bovine plasma.

${ }^{3}$ Spray-dried porcine plasma.

initial BW and blood measurements were analyzed as a completely randomized experimental design using the GLM procedure of SAS (SAS, 1990). Data from calves that died were included in the dataset until date of death. Mortality during the 42-d study was analyzed using the chi-square option of the Mixed Procedure of SAS (SAS, 1990). Significance was declared at $P<0.05$ unless otherwise noted.

\section{RESULTS AND DISCUSSION}

Chemical composition of experimental ingredients (Table 2) was similar and averaged approximately $94 \%$ DM, 81 and $86 \%$ protein, and $4 \%$ fat. Amount of IgG in bovine and porcine plasmas was similar (16.8\% of DM). Ash was nearly $40 \%$ lower in SDPP than in SDBP (4.5 vs. $7.56 \%)$. Much of the reduction in mineral was $\mathrm{P}$, whereas Ca content of SDPP was greater than SDBP.

Chemical composition of experimental CMR was similar (Table 3) and averaged 98\% DM, $21 \% \mathrm{CP}$, and $21 \%$ fat, which were similar to formulated values. Differences in mineral composition were minor and probably did not contribute to differences in animal performance.

Table 3. Chemical composition of experimental diets.

\begin{tabular}{|c|c|c|c|c|}
\hline \multirow[b]{2}{*}{ Nutrient, ${ }^{2} \%$} & \multicolumn{3}{|c|}{ Milk replacer ${ }^{1}$} & \multirow{2}{*}{$\begin{array}{l}\text { Calf } \\
\text { starter }\end{array}$} \\
\hline & WPC & SDBP & SDPP & \\
\hline DM & 98.03 & 97.98 & 97.94 & 89.56 \\
\hline $\mathrm{CP}$ & 21.34 & 21.60 & 20.97 & 24.46 \\
\hline Fat & 20.93 & 21.03 & 21.11 & 7.07 \\
\hline Ash & 7.81 & 7.77 & 7.58 & 4.69 \\
\hline Calcium & 0.96 & 0.87 & 0.92 & 0.42 \\
\hline Phosphorous & 0.77 & 0.77 & 0.72 & 0.72 \\
\hline Potassium & 1.47 & 1.48 & 1.45 & 0.82 \\
\hline Magnesium & 0.14 & 0.13 & 0.14 & 0.22 \\
\hline $\mathrm{ADF}$ & $\ldots$ & $\ldots$ & $\ldots$ & 4.79 \\
\hline
\end{tabular}

${ }^{1}$ Milk replacer: $\mathrm{WPC}=$ calf milk replacer $(\mathrm{CMR})$ containing whey protein concentrate; $\mathrm{SDBP}=\mathrm{CMR}$ containing $5 \%$ spray-dried bovine plasma; SDPP = CMR containing 5\% spray-dried porcine plasma.

${ }^{2}$ Analyses are on a $100 \%$ DM basis, except DM.
Calf starter composition (Table 3) exceeded NRC (1989) recommendations for all nutrients measured.

Blood hematocrit, plasma IgG, and total protein were not different in calves on arrival (Table 4) and were $33.9 \%, 11.5 \mathrm{~g} / \mathrm{L}$, and $5.80 \mathrm{~g} / \mathrm{dL}$, respectively. Mean age at the start of the study (data provided by the producers) was $4.7 \mathrm{~d}$. Plasma total protein and IgG were highly correlated $(\mathrm{r}=0.89, P<0.001)$, indicating that most of the variation in total protein was due to differences in plasma IgG concentration. Prediction of acceptable concentration of plasma IgG (i.e., $10 \mathrm{~g} / \mathrm{L}$ ) occurred at $5.6 \mathrm{~g} / \mathrm{dL}$.

Mortality of calves was reduced by $75 \%$ when SDBP or SDPP were added to the diet (Table 4). Mean day of the study at which mortality occurred was 19,24 , and $40 \mathrm{~d}$ for calves fed WPC, SDBP, and SDPP, respectively. Necropsies were not conducted on all calves; however, clinical signs generally were consistent with enteric infections (diarrhea) when calves died prior to $21 \mathrm{~d}$ of the study. During the $7 \mathrm{~d}$ before death, calves were treated with electrolytes and/or antibiotics for 1.4, 0.3, and $1.5 \mathrm{~d}$ for calves fed WPC, SDBP, and SDPP, respectively. The mean number of days that calves had diarrhea during the $7 \mathrm{~d}$ preceding death was $2.6,1.0$, and $0 \mathrm{~d}$, respectively.

Overall calf mortality during the trial (15 calves, $12.5 \%$ ) was greater than in previous studies conducted at the same facility (Quigley et al., 2000, 2002) and suggests that calves were exposed to significant stress due to transportation, commingling, and pathogen exposure. However, concentrations of IgG on arrival were not correlated with mortality; 7 of 15 calves that died had initial plasma IgG concentration $>10 \mathrm{~g} / \mathrm{L}$.

The observations related to mortality are consistent with other studies whereby inclusion of a biologically active source of oral IgG contributed to reduced mortality in young calves in response to experimental enteric challenge (Snodgrass et al., 1982; Quigley and Drew, 2000; Arthington et al., 2002; Hunt et al., 2002) or onfarm conditions (Morrill et al., 1995; Quigley et al., 2002). Improved survival of young pigs fed diets containing SDPP and challenged with enteropathogens has been reported (Nollet et al., 1999a; Bosi et al., 2001; Torrallardona et al., accepted). Coffey and Cromwell (1995) also reported that weanling pigs housed in an experimental nursery did not grow faster when SDPP was included in the diet; however, pigs housed in a "conventional" nursery grew faster and ate more DM when SDPP was included. The authors suggested that greater pathogen load in the conventional nursery was responsible for differential responses to SDPP in the diet.

Plasma and serum proteins contain IgG that are partially resistant to proteolysis (Roos et al., 1995) and 
Table 4. Least-squares means of animal performance.

\begin{tabular}{|c|c|c|c|c|c|c|}
\hline & \multicolumn{3}{|c|}{ Treatments $^{1}$} & \multirow[b]{2}{*}{ SEM } & \multicolumn{2}{|c|}{ Contrasts $^{2}$} \\
\hline & WPC & SDBP & SDPP & & 1 & 2 \\
\hline \multicolumn{7}{|l|}{$\mathrm{n}$} \\
\hline Begin & 40 & 40 & 40 & $\ldots$ & $\ldots$ & $\ldots$ \\
\hline End & 30 & 37 & 38 & $\ldots$ & & \\
\hline Mortality, \% & 25.0 & 7.5 & 5.0 & 5.1 & 0.003 & NS \\
\hline $\operatorname{IgG}, \mathrm{g} / \mathrm{L}$ & 11.9 & 11.9 & 10.8 & 1.1 & NS & NS \\
\hline Hematocrit, \% & 35.4 & 34.2 & 32.2 & 1.1 & NS & NS \\
\hline Plasma protein, g/dl & 5.79 & 5.81 & 5.79 & 0.13 & NS & NS \\
\hline Age on $\mathrm{d} 0, \mathrm{~d}$ & 4.4 & 5.0 & 4.6 & 0.2 & 0.09 & NS \\
\hline \multicolumn{7}{|l|}{$\mathrm{BW}, \mathrm{kg}$} \\
\hline d 0 & 47.3 & 47.0 & 47.4 & 0.7 & NS & NS \\
\hline d 28 & 49.5 & 50.4 & 49.7 & 0.7 & NS & NS \\
\hline d 42 & 56.4 & 58.2 & 56.8 & 1.1 & NS & NS \\
\hline \multicolumn{7}{|l|}{$\mathrm{ADG}, \mathrm{g} / \mathrm{d}$} \\
\hline d 0 to 28 & 83 & 119 & 80 & 15 & NS & 0.08 \\
\hline d 29 to 42 & 478 & 547 & 481 & 49 & NS & NS \\
\hline d 0 to 42 & 231 & 261 & 218 & 21 & NS & NS \\
\hline \multicolumn{7}{|l|}{ DMI, g/d } \\
\hline $\mathrm{CMR}^{3}$ & 514 & 520 & 517 & 2 & 0.02 & NS \\
\hline Starter $^{3}$ & 158 & 196 & 190 & 14 & 0.05 & NS \\
\hline Total $^{3}$ & 661 & 710 & 684 & 18 & 0.05 & NS \\
\hline Protein intake, $\mathrm{g} / \mathrm{d}^{3}$ & 142 & 154 & 145 & 4 & 0.02 & NS \\
\hline Fat intake, $g / d^{3}$ & 116 & 121 & 120 & 1 & 0.005 & NS \\
\hline Water intake, $\mathrm{L} / \mathrm{d}^{3}$ & 0.2 & 0.2 & 0.2 & 0.1 & NS & NS \\
\hline ADG:DMI, g/kg ${ }^{3}$ & 162 & 263 & 199 & 33 & 0.09 & NS \\
\hline Fecal scores ${ }^{3}$ & 1.67 & 1.58 & 1.61 & 0.03 & 0.06 & NS \\
\hline Scours, $d^{3}$ & 6.36 & 3.89 & 4.69 & 0.54 & 0.009 & NS \\
\hline Electrolytes, $\mathrm{d}^{3}$ & 2.77 & 1.85 & 2.37 & 0.36 & NS & NS \\
\hline Antibiotics, $\mathrm{d}^{3,4}$ & 2.31 & 1.42 & 2.15 & 0.41 & NS & NS \\
\hline
\end{tabular}

\footnotetext{
${ }^{1}$ Treatments: $\mathrm{WPC}=$ calf milk replacer $(\mathrm{CMR})$ containing all-milk ingredients; $\mathrm{SDBP}=\mathrm{CMR}$ containing spray-dried bovine plasma; SDPP $=$ CMR containing spray-dried porcine plasma.

${ }^{2}$ Contrasts: $1=\mathrm{WPC}$ vs. $(\mathrm{SDBP}+\mathrm{SDPP}) / 2 ; 2=\mathrm{SDBP}$ vs. SDPP; NS $=P>0.10$.

${ }^{3}$ Significant effect of week $(P<0.0001)$.

${ }^{4}$ Significant week $\times$ treatment interaction $(P<0.05)$.
}

remain immunologically active, thereby contributing to local intestinal immunity. Circulating IgG move into the lumen of the intestine, where they may also contribute to local intestinal immunity (Besser et al., 1988a, 1988b). In addition to IgG, spray-dried animal plasma may also provide other immunological components that may reduce the incidence and severity of enteric disease. Nollet et al. (1996) fed calves $2 \mathrm{~L}$ of milk $3 \times /$ $\mathrm{d}$ with SDBP at 0,10 , or $25 \mathrm{~g} / \mathrm{L}$. Calves were orally challenged with $10^{10} \mathrm{cfu}$ of Escherichia coli at 12 to $24 \mathrm{~h}$ of age. The spray-dried animal plasma was pasteurized $\left(50^{\circ} \mathrm{C}\right.$ for $\left.15 \mathrm{~min}\right)$ to eliminate IgG activity. Calves fed $25 \mathrm{~g} / \mathrm{L}$ of bovine plasma were protected from enteric challenge with $E$. coli. Calves fed $10 \mathrm{~g} / \mathrm{L}$ showed moderate signs of enteric disease (anorexia, scours, depression), and one calf died. All calves fed $0 \mathrm{~g}$ of bovine plasma died within $7 \mathrm{~d}$ of challenge due to colibacillosis. Others (Mouricout et al., 1990; Sanchez et al., 1993) have also reported an inhibition of adhesion of $E$. coli due to glycoprotein glycans from plasma.
Mean BW at 0,28 , and $42 \mathrm{~d}$ of the study were unaffected by treatment and were $47.2,49.9$, and $57.2 \mathrm{~kg}$, respectively (Table 4). Mean BW gain from d 0 to 28 tended $(P<0.10)$ to be greater when SDBP was fed instead of SDPP; however, the comparison of control and plasma sources was not statistically significant. BW gains for other time periods were unaffected by treatment. The number of animals per treatment in this study was large $(n=40)$, and the resulting CV was low. Differences in BW gain between SDPP and SDBP from 0 to $28 \mathrm{~d}$ was $39 \mathrm{~g} / \mathrm{d}$, which would amount to a difference of $1.1 \mathrm{~kg}$ in BW at the end of the 28-d period. It is unlikely that this difference, though tending toward statistical significance, is biologically meaningful. Generally, BW gains to $42 \mathrm{~d}$ were lower in the current study than in other trials at this facility (Quigley et al., 2000, 2002). Weekly BW (Table 5) changed little during the first 2 wk of the study, but began to increase in a curvilinear fashion thereafter. 
Table 5. Weekly least-squares means of animal performance.

\begin{tabular}{|c|c|c|c|c|}
\hline \multirow[b]{2}{*}{ Item } & \multicolumn{3}{|c|}{ Treatment $^{1}$} & \multirow[b]{2}{*}{ SEM } \\
\hline & WPC & SDBP & SDPP & \\
\hline \multicolumn{5}{|c|}{$\mathrm{BW}, \mathrm{kg}^{2}$} \\
\hline Wk 1 & 45.8 & 46.1 & 46.3 & 0.7 \\
\hline Wk 2 & 45.3 & 45.8 & 46.5 & 0.8 \\
\hline Wk 3 & 47.1 & 47.4 & 47.4 & 0.7 \\
\hline Wk 4 & 49.3 & 50.2 & 49.7 & 0.7 \\
\hline Wk 5 & 51.9 & 53.1 & 52.5 & 0.9 \\
\hline Wk 6 & 55.3 & 57.8 & 56.2 & 1.1 \\
\hline \multicolumn{5}{|c|}{ DM intake, $\mathrm{g} / \mathrm{d}^{2}$} \\
\hline Wk 1 & 435 & 441 & 439 & 2 \\
\hline Wk 2 & 517 & 527 & 527 & 4 \\
\hline Wk 3 & 635 & 638 & 637 & 2 \\
\hline Wk 4 & 701 & 710 & 707 & 3 \\
\hline Wk 5 & 770 & 823 & 793 & 24 \\
\hline Wk 6 & 907 & 1121 & 1005 & 62 \\
\hline \multicolumn{5}{|c|}{ Antibiotic use, $\mathrm{d} / \mathrm{wk}^{2,3}$} \\
\hline Wk 1 & 0.55 & 0.40 & 0.58 & 0.18 \\
\hline Wk 2 & 1.26 & 0.45 & 0.50 & 0.21 \\
\hline Wk 3 & 0.24 & 0.08 & 0.63 & 0.14 \\
\hline Wk 4 & 0.06 & 0.13 & 0.10 & 0.08 \\
\hline Wk 5 & 0.15 & 0.26 & 0.30 & 0.17 \\
\hline Wk 6 & 0.04 & 0.10 & 0.05 & 0.05 \\
\hline \multicolumn{5}{|c|}{ Scours, $\mathrm{d} / \mathrm{wk}^{2}$} \\
\hline Wk 1 & 1.47 & 1.18 & 1.40 & 0.24 \\
\hline Wk 2 & 2.48 & 1.36 & 1.73 & 0.28 \\
\hline Wk 3 & 0.94 & 0.58 & 0.60 & 0.18 \\
\hline Wk 4 & 0.94 & 0.58 & 0.65 & 0.20 \\
\hline Wk 5 & 0.25 & 0.13 & 0.31 & 0.10 \\
\hline Wk 6 & 0.04 & 0.06 & 0.00 & 0.03 \\
\hline
\end{tabular}

${ }^{1}$ Treatments: $\mathrm{WPC}=$ calf milk replacer $(\mathrm{CMR})$ containing all-milk ingredients; $\mathrm{SDBP}=\mathrm{CMR}$ containing spray-dried bovine plasma; SDPP $=\mathrm{CMR}$ containing spray-dried porcine plasma.

${ }^{2}$ Significant effect of week $(P<0.0001)$.

${ }^{3}$ Signficant week $\times$ treatment interaction $(P<0.05)$.

Intake of CMR was greater when SDBP and SDPP were fed; however, the difference was only $5 \mathrm{~g} / \mathrm{d}$ and it is unlikely that this difference, though statistically significant, is biologically meaningful. We calculated metabolizable energy (ME) requirements for calves using 2001 NRC equations (NRC, 2001) and an estimate of 4.75 Mcal of ME/ $/ \mathrm{kg}$ of CMR DM (NRC, 2001). During the first 4 wk of the study, when CMR was the only nutrient source, intake of CMR should have supported approximately 140, 280, 430, and $500 \mathrm{~g}$ of BW gain/d, respectively. Instead, mean BW gains were $-160,-27$, 220 , and $323 \mathrm{~g} / \mathrm{d}$, respectively. These data suggest that either ingredients in CMR were unavailable and ME of CMR were much lower than $4.75 \mathrm{Mcal} / \mathrm{kg}$ of DM, or that ME maintenance requirement was increased due to stress caused by transportation, handling, or disease.

Intakes of total DM and starter were greater when calves were offered CMR containing plasma (Table 4). As a result of increased consumption of starter and CMR, protein and fat intakes were increased when SDBP or SDPP was fed. Weekly intake of total DM (Table 5) showed little difference among treatments to wk 5; however, in the last week of the study, calves fed SDBP tended $(P<0.10)$ to consume more CS than other calves. This increased CS intake was probably responsible for increased BW gain during the last $2 \mathrm{wk}$ of the study. Morrill et al. (1995) also reported increased BW gain in calves fed bovine or porcine plasma over calves fed CMR containing only milk proteins.

Efficiency of BW gain tended $(P=0.09)$ to be greater when calves were fed CMR containing plasma (Table 4). Weekly means of feed efficiency (data not shown) increased to wk 4 , then were relatively similar to the end of the study. Increased efficiency to wk 4 was probably due to increased rate of CMR feeding and improved BW gain.

Mean water intake during the 42-d period was unaffected by experimental treatment and was $0.2 \mathrm{~L} / \mathrm{d}$. This amount of water intake was markedly lower than intake from previous studies (Quigley et al., 2002) and was probably influenced by the relatively high liquid intake early in the study followed by cold temperatures (mean daily high temperature from d 19 to 42 was $0.9^{\circ} \mathrm{C}$ ) later in the study when amount of water from 
CMR was reduced. Low daily ambient temperatures were $\leq 0^{\circ} \mathrm{C}$ for $32 \mathrm{~d}$ during the study, which resulted in a lack of available water due to freezing. Only during the sixth week did intake of water increase, and then only to 0.3 to $0.5 \mathrm{~L} / \mathrm{d}$. During the first week of the study, calves consumed greater amounts of water, which may have been due to relatively high temperatures (mean daily high temperature during the first week was $21.9^{\circ} \mathrm{C}$ ) and possibly due to stress of transportation.

Fecal scores tended $(P<0.06)$ to be lower, and the number of days that calves scoured (fecal score $>2$ ) was lower $(P<0.01)$ when calves were fed SDPP or SDBP (Table 4). These results are consistent with lower mortality. However, use of electrolytes and antibiotics was not statistically reduced when SDBP or SDPP was fed. Weekly fecal scores peaked at 2.0 to 2.2 during the second week, then declined to the end of the study. Calves fed control CMR had higher fecal scores during the second and third weeks of the study than other calves. Weekly mean number of days that calves had scours (Table 5) indicated clearly that calves fed CMR containing WPC peaked higher during the second and third weeks of the study. Thereafter, number of days calves had scours declined in all calves and reached nearly 0 by $6 \mathrm{wk}$. Antibiotic use was affected by a weekby-treatment interaction $(P<0.05)$ and were higher for calves fed WPC during the second week of the study (Table 5). This peak correlated closely with increased scours, indicating that most antibiotic use was in response to enteric infection.

Porcine plasma used in this study was heated to remove insoluble material and to increase IgG to concentration similar to SDBP. Consequently, the chemical composition of the plasma differed (Table 2), although the chemical composition of experimental CMR were similar. Heat treatment of plasma is not a common practice in the industry; rather, it was our goal to produce plasmas with similar IgG content. Differences in performance between calves fed SDBP and SDPP may have been due to differences in species origin of plasmas, differences in chemical or nutrient composition of plasmas, or method of processing (Hansen et al., 1993).

\section{CONCLUSIONS}

Including SDBP or SDPP in CMR formulas reduced morbidity and mortality of young milk-fed calves. This observation is consistent with other research indicating that dietary plasma as a source of biologically active proteins, including immunoglobulins, is of value to animals during periods of stress. Differences in performance between SDBP and SDPP were small and may have been due to differences in processing or the initial source (bovine vs. porcine) or may have been due to the low CV among treatments.

\section{ACKNOWLEDGMENTS}

The authors acknowledge the help of R. Strohbehn and the laboratory assistance of S. Glick and the APC Calf Research Unit staff for calf care.

\section{REFERENCES}

Association of Official Analytical Chemists. 1990. Official Methods of Analysis. Vol. I. 15th ed. AOAC, Arlington, VA.

Arthington, J. D., C. A. Jaynes, H. D. Tyler, S. Kapil, and J. D. Quigley, III. 2002. The use of bovine serum protein as an oral support therapy following coronavirus challenge in calves. J. Dairy Sci. 85:1249-1254.

Besser, T. E., C. C. Gay, T. C. McGuire, and J. F. Evermann. 1988a. Passive immunity to rotavirus infection associated with transfer of serum antibody into the intestinal lumen. J. Virology. 62:2238-2242.

Besser, T. E., T. C. McGuire, C. C. Gay, and L. C. Pritchett. 1988b. Transfer of functional immunoglobulin G (IgG) antibody into the gastrointestinal tract accounts for IgG clearance in calves. J. Virology. 62:2234-2237.

Bosi, P., I. K. Han, H. J. Jung, K. N. Neo, S. Perini, A. M. Castellazzi, L. Casini, D. Creston, and C. Gremokolini. 2001. Effect of different spay dried plasmas on growth, ileal digestibility, nutrient deposition, immunity and health of early weaned pigs challenged with E. coli K88. Asian-Aust. J. Anim. Sci. 14:1138-1143.

Coffey, R. D., and G. L. Cromwell. 1995. The impact of environment and antimicrobial agents on the growth response of early-weaned pigs to spray-dried porcine plasma. J. Anim. Sci. 73:2532-2539.

Etzel, L. R., R. E. Strohbehn, and J. K. McVicker. 1997. Development of an automated turbidimetric immunoassay for quantification of bovine serum immunoglobulin G. Am. J. Vet. Res. 58:1201-1205.

Hansen, J. A., J. L. Nelssen, R. D. Goodband, and T. L. Weeden. 1993. Evaluation of animal protein supplements in diets of earlyweaned pigs. J. Anim. Sci. 71:1853-1862.

Heinrichs, A. J., S. J. Wells, and W. C. Losinger. 1995. A study of the use of milk replacers for dairy calves in the United States. J. Dairy Sci. 78:2831-2837.

Hunt, E., Q. Fu, M. U. Armstrong, D. K. Rennix, D. W. Webster, J. A. Galanko, W. Chen, E. M. Weaver, R. A. Argenzio, and J. M. Rhoads. 2002. Oral bovine serum concentrate improves cryptosporidial enteritis in calves. Ped. Res. 51:370-376.

Larson, L. L., F. G. Owen, J. L. Albright, R. D. Appleman, R. C. Lamb, and L. D. Muller. 1977. Guidelines toward more uniformity in measuring and reporting calf experimental data. J. Dairy Sci. 60:989-991.

Littell, R. C., P. R. Henry, and C. B. Ammerman. 1998. Statistical analysis of repeated measures data using SAS procedures. J. Anim. Sci. 76:1216-1231.

Morrill, J. L., J. M. Morrill, A. M. Feyerherm, and J. F. Laster. 1995. Plasma proteins and a probiotic as ingredients in milk replacer. J. Dairy Sci. 78:902-907.

Mouricout, M., J. M. Petit, J. R. Carias, and R. Julian. 1990. Glycoprotein glycans that inhibit adhesion of Escherichia coli mediated by K99 fimbriae. Treatment of experimental colibacillosis. Infect. Immun. 58:98-106.

National Research Council. 2001. Nutrient Requirements of Dairy Cattle. 7th rev. ed. Natl. Acad. Sci., Washington, DC.

Nollet, H., P. Deprez, E. van Driessche, and E. Muylle. 1999a. Protection of just weaned pigs against infection with $\mathrm{F} 18^{+}$Escherichia coli by non-immune plasma powder. Vet. Microbiol. 65:37-45.

Nollet, H., H. Laevens, P. Deprez, R. Sanchez, E. Van Driessche, and E. Muylle. 1999b. The use of non-immune plasma powder in the prophylaxis of neonatal Escherichia coli diarrhoea in calves. J. Vet. Med. A. 46:185-196. 
Quigley, J. D., III, and J. K. Bernard. 1996. Milk replacers with or without animal plasma for dairy calves. J. Dairy Sci. 79:18811884.

Quigley, J. D., III, and M. D. Drew. 2000. Effects of oral antibiotics or IgG on survival, health and growth in dairy calves challenged with Escherichia coli. Food Ag. Immunol. 12:311-318.

Quigley, J. D., III, C. A. Jaynes, M. L. Miller, E. Schanus, H. ChesterJones, G. D. Marx, and D. M. Allen. 2000. Effects of hydrolyzed spray dried red blood cells in milk replacer on calf intake, body weight gain and efficiency. J. Dairy Sci. 83:788-794.

Quigley, J. D., III, C. J. Kost and T. M. Anspach. 2002. Effects of spray-dried animal plasma in milk replacers or additives containing serum on growth and health of calves. J. Dairy Sci. 85:413-421.

Roos, N., S. Mahe, R. Benamouzig, H. Sick, J. Rautureau, and D. Tome. $1995 .{ }^{15} \mathrm{~N}$-labelled immunoglobulins from bovine colostrum are partially resistant to digestion in human intestine. J. Nutr. $125: 1238-1244$
Sanchez, R., L. Kanarek, J. Koninkx, H. Hendriks, P. Lintermans, A. Vertels, G. Charlier, and E. Van Driessche. 1993. Inhibition of adhesion of enterotoxigenic Escherichia coli cells expressing F17 fimbriae to small intestinal mucus and brush-border membranes of young calves. Microb. Pathogen. 15:407-419.

SAS/STAT User's Guide, 4th ed. 1990. SAS Inst., Inc., Cary, NC.

Snodgrass, D. R., J. Stewart, J. Taylor, F. L. Krautil, and M. L. Smith. 1982. Diarrhoea in dairy calves reduced by feeding colostrum from cows vaccinated with rotavirus. Res. Vet. Sci. 32:70-73.

Torrallardona, D., M. R. Conde, I. Badiola, J. Polo, and J. Brufau. 2003. Effect of spray dried animal plasma and colistin on performance, structure of small intestine and ileal and caecal microbiology of weanling pigs experimentally infected with Escherichia coli K99. J. Anim. Sci. (In press).

Williams, A. P. 1994. Amino acid requirements of the veal calf and beef steer. Page 329-349 in Amino Acids in Farm Animal Nutrition. J. P. F. D'Mello, ed. CAB International, Oxon, United Kingdom. 